\title{
Daily Energy Balance and Protein Gain Among Pan troglodytes verus in the Taï National Park, Côte d'Ivoire
}

\author{
Antoine K. N'guessan • Sylvia Ortmann • \\ Christophe Boesch
}

Received: 27 June 2008 / Accepted: 9 April 2009/

Published online: 13 May 2009

(C) The Author(s) 2009. This article is published with open access at Springerlink.com

\begin{abstract}
Energy balance and protein gain contribute significantly to an animal's survival. Although data are available for certain species in captive settings, there is little information on these factors for primates living in their natural environments. In this preliminary study, we combined detailed behavioral, phonological, and chemical data for a well habituated chimpanzee community from the Taï National Park, Côte d'Ivoire, with estimates of energy gain and expenditure from captive chimpanzees and humans to investigate how energy balance and protein gain across age-sex categories are affected by seasonal variations in food availability and how chimpanzees correspondingly alter their feeding and daily journey length (DJL). Comparisons between fruiting seasons characterized by varying quantities and qualities of available food revealed that food quality had the largest effect on individual energy balance and protein gain. Within given fruit seasons, energy balance and protein gain did not vary among age-sex categories. However, there was, variation across seasons among adult males and young of both sexes, but not among adult females. Our study revealed important effects of periods of food scarcity to which chimpanzees reacted by reducing their DJL and increasing their feeding time.
\end{abstract}

Keywords chimpanzee · energy balance · fruit seasons · protein gain · Taï National Park

\section{A. K. N'guessan ( $\square)$}

Swiss Centre of Scientific Research, 01 BP 1303, Abidjan 01, Côte d'Ivoire

e-mail: nguekoi@yahoo.fr

\section{A. K. N'guessan}

University of Cocody, Abidjan, Côte d'Ivoire

\section{A. K. N'guessan • C. Boesch}

Taï Chimpanzee Project, Abidjan, Côte d'Ivoire

\section{A. K. N'guessan • C. Boesch}

Max Planck Institute for Evolutionary Anthropology, Leipzig D-04103, Germany

\section{S. Ortmann}

Institute for Zoo and Wildlife Research, Berlin 10252, Germany 


\section{Introduction}

Energy balance and protein gain are important factors for an animal's diet quality and overall well-being. Animals require energy for basal metabolic functions, muscular activity, tissue formation, reproduction, and lactation (National Research Council 2003). Animals also require protein and its constituent amino acids for growth and maintenance of body tissues. The absence of both energy and protein results in protein-energy malnutrition (PEM; also known as kwashiorkor and marasmus) (Ausman et al. 1989; Coward and Lunn 1981; Whitehead 1980; Wilgram et al. 1958). Thus, when evaluating diet quality of an organism, it is essential to determine the energy and protein requirements of the animals under study as well as the supply of these elements in their surroundings.

Although the nutritional requirements of humans and domestic animals are well known (Food and Agriculture Organization of the United Nations. et al. 2004; Kindt et al. 1983; Pellet 1990), the same cannot be said for nonhuman primates, especially for those living in natural habitats. There are several reasons for this, including the difficulties in observing wild-living individuals and the high time and monetary costs of conducting such studies (Barton 1992; Chivers 1998; Whiten et al. 1991). Estimates of energy and protein requirements are all the more lacking, and are usually inferred from human data. For example, Knott (1998) determined that male and female orangutans needed 3344 and $1512 \mathrm{kcal} / \mathrm{day}$, respectively, based on the $40 \mathrm{kcal} / \mathrm{kg}$ /day estimate from human studies (National Research Council 2003). For chimpanzees, no clear estimates are available concerning protein requirements, although the National Research Council (2003) estimated that a young captive chimpanzee of 10-24 kg body mass requires $<3 \mathrm{~g} / \mathrm{kg}$ of protein per day. The values increase by $25 \%$ during gestation and by $50 \%$ during lactation (Key and Ross 1999).

It is a challenge to address these issues for animals living in their natural habitats because measurements of nutrient intake and energy expenditure are problematic. In this preliminary study, we aimed to estimate daily energy balance and daily protein gain across age-sex classes for well habituated chimpanzees in the Taï National Park, Côte d'Ivoire. Further, we examined the influence of seasonal variation on energy balance and protein gain as well as behavioral adaptations of chimpanzees to seasonal variation of food availability. We evaluated 3 main hypotheses:

1) Daily energy balance will differ across age categories.

2) Daily energy balance and protein gain will be sensitive to food availability.

3) Chimpanzees will show behavioral flexibility in response to the availability of energy and protein.

We predicted 1) that daily energy balance is neutral in adult chimpanzees, but positive in young individuals; 2) that protein gain is lower during periods of low food availability, and quality of fruits available is the principal factor that influences energy balance and protein gain, and 3) that chimpanzees adapt their energy expenditure and time spent feeding to seasonal variations in food availability to avoid energy imbalances across the year. 


\section{Methods}

\section{Study Site}

We conducted the study at Taï National Park in the southwest of Côte d'Ivoire. The park is the largest remaining tropical rain forest in West Africa and covers 555,000 ha. Researchers have studied the North group chimpanzees since 1979, and the community has been fully habituated to the presence of human observers since 1984 (Boesch and Boesch-Achermann 2000).

\section{Behavioral Data}

We collected data for 3 periods over 3 years: July 2003-May 2004, July 2004-April 2005, and from September 2005-July 2006. We investigated only young individuals (juveniles and adolescents) and adults (Boesch and Boesch-Achermann 2000; Goodall 1986; Nishida 1990), resulting in a total of 13 subjects (Table I). We used focal-animal sampling continuously from dawn to dusk (Altmann 1974; Martin and Bateson 1986). Observed individuals and observation time are represented in Table I. We recorded the following data during all feeding bouts: food type and name (fruit, meat, leaf, and species), start and end time of feeding bout, and the quantity of ingested food. To estimate the quantity of food ingested, we counted all food consumed on the ground (fruits, nuts cracked using a tool, pith and stem of herbaceous plants, mushrooms, larvae) and estimated the amount of food ingested per minute for small fruits, leaves eaten in trees, and termites consumed on the ground. We estimated ingestion rate every $10 \mathrm{~min}$, whenever possible, to be sure to cover all periods of the feeding bouts (beginning- middle-end). For large fruits, like

Table I Observed individuals and total observation time

\begin{tabular}{llll}
\hline Name & Category & Age (yr) & OT (mn) \\
\hline Belle & AF & 28 & 9319 \\
Fossey & AF & 25 & 10,306 \\
Mystere & AF & 29 & 9697 \\
Narcisse & AF & 29 & 9193 \\
Perla & AF & 28 & 2541 \\
Venus & AF & 26 & 9133 \\
Roxane & Y & 10 & 8758 \\
Fedora & Y & 11 & 8316 \\
Pandora & Y & 9 & 1911 \\
Mozart & Y & 9 & 9811 \\
Noureyev & Y & 7 & 10,755 \\
Marius & AM & 22 & 3894 \\
Nino & AM & 16 & 21,230 \\
\hline
\end{tabular}

$\mathrm{OT}=$ observation time; $\mathrm{AF}=$ adult female; $\mathrm{Y}=$ young (juvenile and adolescent); $\mathrm{AM}=$ adult. male 
Treculia africana, and meat, we estimated the portion obtained by our focal individual during the feeding bout. Finally, when chimpanzees consumed ants, we counted the number of handfuls of larvae or the number of fishing sticks used to obtain adult ants.

We marked the position of our target individual every 30 min on a map of the territory covered by a virtual grid of $0.5 \mathrm{ha} / \mathrm{cell}$. At the end of each day, we used these points to calculate the daily journey length (DJL)

\section{Phenological Data}

We measured food availability monthly via 7 phenological transects of $4 \mathrm{~km}$ each (666 individual trees and 44 food species) in the focal community's territory (Anderson et al. 2002; Boesch et al. 2006). We collected the following information for each transect: presence or absence of fruits, color of fruits, presence or absence of ripe fruits, location of fruits (in tress or on the ground), presence or absence of food remains, and an estimate of number of fruit per cubic meter in the canopy. An experienced field assistant collected the phenological data.

\section{Nutritional Analyses}

We collected food samples (fruits, leaves, pith of herbaceous plants, insects and mushrooms), weighed them (whole sample and similar portion consumed), and stored them in liquid nitrogen. We lyophilized samples at the Swiss Centre for Scientific Research (CSRS) in Abidjan, Côte d'Ivoire and sent them to the Institute for Zoo and Wildlife Research (IZW), Berlin, Germany for nutritional analysis using the following techniques:

Dry matter We obtained an initial dry matter mass at the CSRS by calculating the difference in mass between the fresh and lyophilized samples. Before beginning analyses at the IZW we dried a portion of the samples at $105^{\circ} \mathrm{C}$ for $24 \mathrm{~h}$ to obtain a new dry matter because transfer and preservation conditions allowed humidity to affect the samples. We report the chemical composition of samples in relation to the heat-dried matter.

Inorganic Matter (Ash) We determined the quantity of inorganic matter by burning samples at $550^{\circ} \mathrm{C}$ for $2 \mathrm{~h}$. The process removes the organic matter and leaves the inorganic mineral as residue.

Indigestible Carbohydrates (Fiber) We used the detergent system of fiber analysis (Van Soest 1994) to estimate the amount of indigestible carbohydrates in the samples. The method consists of dissolving soluble cellular components, hemicelluloses and celluloses, successively to obtain neutral detergent fiber (NDF), acid detergent fiber (ADF), and acid detergent lignin (ADL) or lignin, sequentially.

Crude Protein $(C P)$ We determined nitrogen content via Dumas' combustion technique (Buckee 1994) at high temperature $\left(c a .950^{\circ} \mathrm{C}\right)$ in pure oxygen, using a Rapid N III analyzer (Elementar Analyser Systeme GmbH, Hanau, Germany). We used a factor of 6.25 to convert nitrogen content into protein: crude protein $(\% \mathrm{DM})=6.25 \times \mathrm{N}(\% \mathrm{DM})$. 
Lipids (L) We extracted lipids with ethyl ether via a fully automatic Soxhlett-system (Soxtherm; Gerhardt Laboratory Systems, Königswinter, Germany).

Total Nonstructural Carbohydrates (TNC) We used the following equation to calculate the amount of total nonstructural carbohydrates (simple sugars like monosaccharide and disaccharides, and complex polysaccharides):

$$
\% \mathrm{TNC}=100-\% \mathrm{~L}-\% \mathrm{CP}-\% \mathrm{NDF}-\% \mathrm{ash}
$$

We predicted the metabolizable energy of foods via standard conversion factors (also known as physiological fuel values). Based on dry matter, we used $4 \mathrm{kcal} / \mathrm{g}$ for CP and TNC and $9 \mathrm{kcal} / \mathrm{g}$ for L (National Research Council 2003). NDF also provide energy to organisms, but symbiotic bacteria responsible for fermentation use a portion of this energy for their own growth. The portion available to the host is estimated to be $1.6 \mathrm{kcal} / \mathrm{g}$ (Conklin-Brittain et al. 2006). The estimation is based on studies from captive chimpanzees fed domestic vegetables, suggesting that we are likely to have overestimated the contribution of NDF to metabolizable energy (Livesey 1995, 2001).

For each food, we calculated predicted metabolic energy (PME) per gram of dry matter as:

$$
\mathrm{PME}(\mathrm{kcal} / \mathrm{g})=(4 \times \% \mathrm{CP}+4 \times \% \mathrm{TNC}+9 \times \% \mathrm{~L}+1.6 \times \% \mathrm{NDF}) / 100
$$

For fruits from which we extracted juice and rejected fiber, i.e., fruit wadges, we analyzed both fresh whole fruits and the wadges, and calculated PME as the difference in the chemical composition of the 2 samples.

\section{Daily Energy Balance}

The daily energy balance (DEB) is the difference between the daily energy gain (DEG) and the total daily energy expenditure (TDEE).

$$
\mathrm{DEB}=\mathrm{DEG}-\mathrm{TDEE}
$$

The product of the PME of a food (a) and its total daily mass gives the predicted daily energy $\left(\mathrm{PDE}_{\mathrm{i}}\right)$ provided by the food. The sum of the PDEis of different foods eaten during the day gives the daily energy gain:

$$
\mathrm{DEG}=\sum \mathrm{PDE}_{\mathrm{i}}
$$

The total daily energy expenditure (TDEE) is the sum of energy expended for maintaining the basal metabolic rate (BMR) and the energy expended for all physical activities. We added $25 \%$ to the TDEE value for pregnant females and $50 \%$ for lactating females (Key and Ross 1999).

We defined the following principal activities: travel (Et); climbing in trees to feed (Ec); nut cracking (we distinguish cracking time from eating time; En); eating (Ee) measured via the duration of feeding bouts (for nuts, we subtracted cracking time); and other activities (Eo), including rest and social activities. Thus,

$$
\mathrm{TDEE}=\mathrm{BMR}+\mathrm{Et}+\mathrm{Ec}+\mathrm{En}+\mathrm{Ee}+\mathrm{Eo}
$$


We used Kleiber's equation (1947) for BMR as suggested by Kurland and Pearson (1986):

$$
\mathrm{BMR}=70 M^{0.75} \mathrm{kcal}^{*} 24 h^{-1}
$$

wherein $M$ is body mass.

For Eo and Ee, we used estimates from Leonard and Robertson (1997), who showed that one can estimate energetic costs related to an activity A in relation to BMR by the following equation:

$$
\mathrm{A}=(\mathrm{DA} \times \mathrm{BMR} \times t) * 24^{-1} \mathrm{kcal}
$$

wherein DA is a coefficient specific to each activity and $t$ is time in hours spent on activity A. The principal coefficients for DA that Leonard and Robertson (1997) used are $\mathrm{D}_{\text {sleep }}=1, \mathrm{D}_{\text {rest }}=1.25, \mathrm{D}_{\text {eating }}=1.38$, and $\mathrm{D}_{\text {social activity }}=2.35$.

We used $\mathrm{D}_{\text {eating }}=1.38$ and $\mathrm{D}=1.25$ for all other activities during rest periods because our focal individuals are less active owing to the small size of the group.

For traveling, climbing, and nut cracking, we used the following estimates:

Energy expenditure for travel (Et) To calculate the energy spent by chimpanzees traveling in the forest, we used the formula proposed by Taylor et al. (1982) for chimpanzees in captivity and used for wild chimpanzees by Pontzer and Wrangham (2004). We could not use the more recent formula, based on the walking costs of adult chimpanzees (Sockol et al. 2007), because we did not have $V_{\text {musc }}$ (volume of muscle activated per unit of ground force) or $t_{c}$ (duration of foot-ground contact time). Moreover, the values of body mass used to establish this formula are higher than those of our study subjects.

Taylor et al. (1982) proposed that a chimpanzee with a body mass $M$ and walking velocity $v$ consumes a volume of oxygen $\mathrm{VO}_{2}\left(\mathrm{ml} \cdot \mathrm{kg}^{-1}\right.$ and $\left.\mathrm{ml} \cdot \mathrm{s}^{-1}\right)$ according to the following formula:

$$
\mathrm{VO}_{2}=0.523 \mathrm{M}^{-0.298} * v+0.345 \mathrm{M}^{-0.157} \mathrm{ml} \cdot \mathrm{kg}^{-1}
$$

The energy expended is then deduced from the volume of oxygen using:

$$
11 \text { of } \mathrm{O}_{2}=4.8 \mathrm{kcal}
$$

We used the walking velocity of Mahale chimpanzees, estimated as $0.88 \mathrm{~m} . \mathrm{s}^{-1}$ for males, $0.78 \mathrm{~m} \cdot \mathrm{s}^{-1}$ for females and $0.75 \mathrm{~m} \cdot \mathrm{s}^{-1}$ for females carrying an infant and for young individuals (Hunt 1989).

For body mass, we used values for west African chimpanzee from Smith and Jungers (1997): $46.3 \mathrm{~kg}$ for adult males and $41.6 \mathrm{~kg}$ for adult females. We estimated the body mass of young individuals as $20 \mathrm{~kg}$ based on an estimate of $15 \mathrm{~kg}$ for Gombe (Pusey 1990) and adding $5 \mathrm{~kg}$ based on morphological differences between Gombe and Taï chimpanzees (Zihlman et al. 2007).

We thus obtain with formula $(\mathrm{g})$ :

$$
\text { Adult males: } \begin{aligned}
\mathrm{VO}_{2} & =0.523 *(46.3)^{-0.298} *(0.88)+0.345(46.3)^{-0.157} \mathrm{ml} \cdot \mathrm{kg}^{-1} \cdot \mathrm{s}^{-1} \\
\mathrm{VO}_{2} & =0.38 \mathrm{ml} \cdot \mathrm{kg}^{-1} \cdot \mathrm{s}^{-1}
\end{aligned}
$$


Adult females : $\begin{aligned} \mathrm{VO}_{2} & =0.523 *(41.6)^{-0.298} *(0.78)+0.345(41.6)^{-0.157} \mathrm{ml} \cdot \mathrm{kg}^{-1} \cdot \mathrm{s}^{-1} \\ \mathrm{VO}_{2} & =0.37 \mathrm{ml} \cdot \mathrm{kg}^{-1} \cdot \mathrm{s}^{-1}\end{aligned}$

Young individuals : $\begin{aligned} \mathrm{VO}_{2} & =0.523 *(20)^{-0.298} *(0.75)+0.345(20)^{-0.157} \mathrm{ml} \cdot \mathrm{kg}^{-1} \cdot \mathrm{s}^{-1} \\ \mathrm{VO}_{2} & =0.41 \mathrm{ml} \cdot \mathrm{kg}^{-1} \cdot \mathrm{s}^{-1}\end{aligned}$

Using formula (h) with the body mass value, we obtain:

$$
\begin{aligned}
& \text { Et }(\text { males })=0.38^{*} 10^{-3} 4.8 * 46.3 \mathrm{kcal} \cdot \mathrm{s}^{-1} \\
& \mathrm{Et}(\text { males })=8.45^{*} 10^{-2} \mathrm{kcal} \cdot \mathrm{s}^{-1} \\
& \mathrm{Et}(\text { females })=0.37 * 10^{-3} * 4.8 * 41.6 \mathrm{kcal} \cdot \mathrm{s}^{-1} \\
& \mathrm{Et}(\text { females })=7.31 * 10^{-2} \mathrm{kcal} \cdot \mathrm{s}^{-1} \\
& \operatorname{Et}(\text { young })=0.41 * 10^{-3 * 4.8} * 20 \mathrm{kcal} \cdot \mathrm{s}^{-1} \\
& \operatorname{Et}(\text { young })=4.0^{*} 10^{-2} \mathrm{kcal} \cdot \mathrm{s}^{-1}
\end{aligned}
$$

Energy expenditure for climbing (Ec) Due to the lack of data for chimpanzees, we used the formula derived for humans and used by Pontzer and Wrangham (2004) for climbing. A series of formulas proposed by Billat et al. (1995), Booth et al. (1999), Mermier et al. (1997), Watts et al. (2000), Watts and Drobish (1998), all give approximately the same results, so we opted for the model of Mermier et al. (1997), because of its similarity with Et. According to these authors, energy spent for climbing is equivalent to the energy spent walking with a walking velocity of $1.9 \mathrm{~m} \cdot \mathrm{s}^{-1}$. Following the same process as for previous calculations (formulas $\mathrm{g}$ and $\mathrm{h}$ ), we obtain:

$$
\begin{aligned}
\mathrm{Ec}(\text { males }) & =0.13 \mathrm{kcal} \cdot \mathrm{s}^{-1} \\
\mathrm{Ec}(\text { females }) & =0.12 \mathrm{kcal} \cdot \mathrm{s}^{-1} \\
\mathrm{Ec}(\text { young }) & =0.07 \mathrm{kcal} \cdot \mathrm{s}^{-1}
\end{aligned}
$$

To climb a tree with height $\mathrm{h}$ and a climbing velocity of $0.5 \mathrm{~m} \cdot \mathrm{s}^{-1}$ (Pontzer and Wrangham 2004) we obtain $t=2 h$ (s), such that:

$$
\begin{aligned}
\mathrm{Ec}(\text { males }) & =0.13 * 2 h \mathrm{kcal} \\
\mathrm{Ec}(\text { females }) & =0.12 * 2 h \mathrm{kcal} \\
\mathrm{Ec}(\text { young }) & =0.07 * 2 h \mathrm{kcal} \\
\mathrm{Ec}(\text { mean }) & =0.22 * h \mathrm{kcal}
\end{aligned}
$$

Additionally, we used tree heights from Aubréville (1936).

Energy expenditure for nut cracking (En) Chimpanzees at Taï mainly crack 4 species of nuts. In order of increasing hardness, these are Coula edulis, Detarium senegalense, Parinari excelsa and Panda oleosa (Boesch and Boesch-Achermann 2000). To determine the energy spent for each hit, we used formulas proposed by Günther and Boesch (1993). An estimation of the energy expended to open a nut given the mean number of hits is $1.06,0.70,3.20$, and $5.80 \mathrm{~kJ}$ for the 4 nuts, respectively.

Among the daily energy expenditures, chimpanzees may modify Et voluntarily to influence their daily energy balance. 
Food Availability and Fruit Seasons

We defined 4 fruit seasons by the quantity and diversity of fruits available, the energy providing rate, and the protein providing rate of these fruits. We expressed the quantity of fruits available as the biomass abundance index (BA; Savini et al. 2008), which is a combination of the food availability index (FAI; Anderson et al. 2002) and the biomass per cubic meter of canopy $(b)$. FAI is obtained from density $(D)$, basal area of the trunk $(B)$, and the proportion $(P)$ of plants with available fruits during our visit.

Thus, monthly FAI is the sum of $k$ plant species:

$$
\underset{k=1}{\mathrm{~F} A \mathrm{I}}=\sum \mathrm{D}_{k} \mathrm{~B}_{k} \mathrm{P}_{\mathrm{k}}
$$

FAI is a theoretical value that does not take into account the actual amount of fruit borne by trees. Combining the number of fruits by cubic meter of canopy and FAI, we obtained the biomass abundance (BA; Savini et al. 2008):

$$
\mathrm{BA}=\mathrm{FAI}^{*} b
$$

$\mathrm{BA}$ is expressed in kilograms per cubic meter per hectare.

The energy providing rate (EPR) is a qualitative aspect of fruit availability at a given time. This is a score attributed monthly using the mean energy ingestion rate (EIR) of principal fruits eaten.

$$
\mathrm{EIR}=\mathrm{PME}^{*} m^{*} t^{-1}
$$

wherein PME is the predicted metabolic energy of the food, $m$ is the mass of food eaten, and $t$ is the duration of the feeding bout.

Thus, for a given month, the EPR of main foods is:

$$
\underset{k=1}{\mathrm{EPR}}=\sum \mathrm{EIR}^{*} n^{-1}
$$

We defined the protein providing rate (PPR) in the same way.

\section{Statistical Analyses}

To compare energy balance and protein gain across seasons and between categories of individuals, we used a Kruskal-Wallis test. To test for differences between seasons and categories of individuals, we used Mann-Whitney $U$ tests. To examine the relationship between food availability and DJL and between food availability and time spent eating, we used Spearman rank correlations. To determine how the quantitative and qualitative aspects of fruit availability affect energy balance, we used multiple linear regressions. We log transformed dependent variables when normality and homoscedasticity conditions were not fulfilled. We detected no colinearity problems.

For daily energy and protein gain, we considered only days when we analyzed $\geq 90 \%$ of the total mass of food consumed. As such, we have 127 days in our data set distributed as follows: 9 with 100\% food analyzed, 82 with $96-99 \%$ of food analyzed and 36 with $90-95 \%$ of food analyzed. 


\section{Results}

\section{Characteristics of Fruit Seasons}

Fruit seasons were significantly distinct in fruit diversity and energy and protein providing rates but were similar in biomass quantity of fruits available (Fig. 1). We named each season after the most common food species eaten by chimpanzees: the Sacoglottis or Saco season (Sacoglottis gabonensis), extending from August to September; the Coula season (Coula edulis) from November to January; the Parinari-Dialium season (Parinari excelsa and Dialium aubrevillei) from February to April; and the Interseason, which does not contain any particularly dominant fruit and covers April to July. The Coula season was by far the most favorable in all aspects of providing more energy and nutrients, followed by the Interseason. The Pari-Dialium season had a low rate of providing energy and protein, but the Saco season was the lowest.

\section{Energy Balance}

Within each fruit season, there was no significant difference in energy balance across categories of individuals $\left(\chi^{2}=4.741 ; N=114 ; \mathrm{df}=2 ; p=0.09\right)$. However, the interseason comparison showed that energy balance varied for young and adult males. For adult females, energy balance was similar across all seasons, suggesting that they used the best strategy for energy management throughout the year $\left(\chi^{2}=5.14 ; N=48 ; \mathrm{df}=3\right.$; $p=0.162$; Fig. 2). For adult males, energy balance was higher during the Coula season and the Interseason vs. the Saco and Parinari-dialium seasons (Coula > Saco": $p=0.002 ; U=5 ; N=17$, Coula $>$ PariDialium: $U=7 ; N=17 ; p=0.004)$. The seasonal variation in the energy balance of young individuals was similar to that of adult males: Coula > Saco: $U=5 ; N=24 ; p<0,001$, Coula $>$ PariDialium: $U=2 ; N=24 ; p<0,001$ ). Contrary to our prediction, biomass quantity and fruit diversity did not influence the energy balance of chimpanzees $\left(R^{2}=0.48 ; F_{(4 ; 122)}=28.71 ; p<0.001\right.$; Table II).

On average, energy balance was positive, but all categories of individuals showed days with negative energy balance. Young individuals had negative energy balance

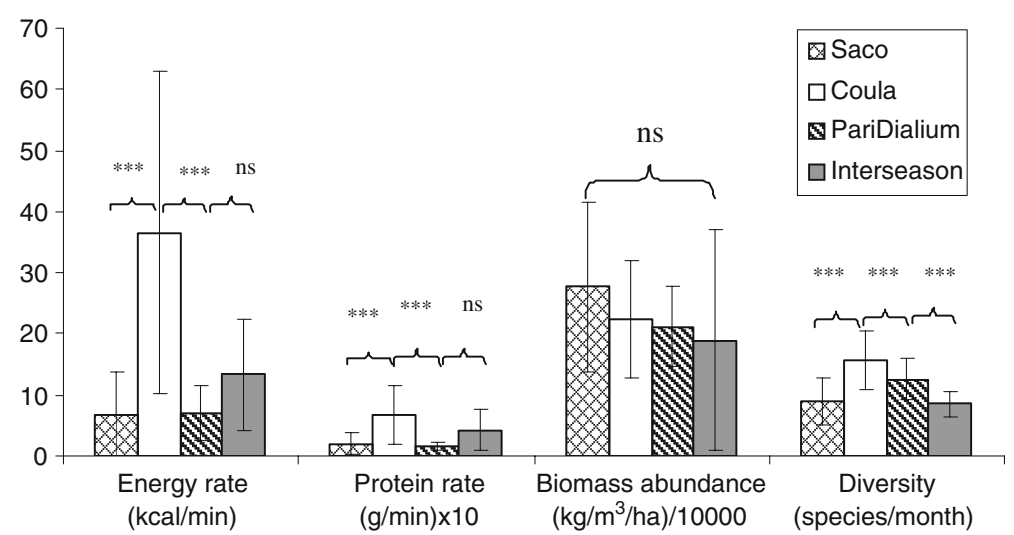

Fig. 1 Characteristics of different fruit seasons. ns $=$ nonsignificant; $* * * p<0.001)$. 


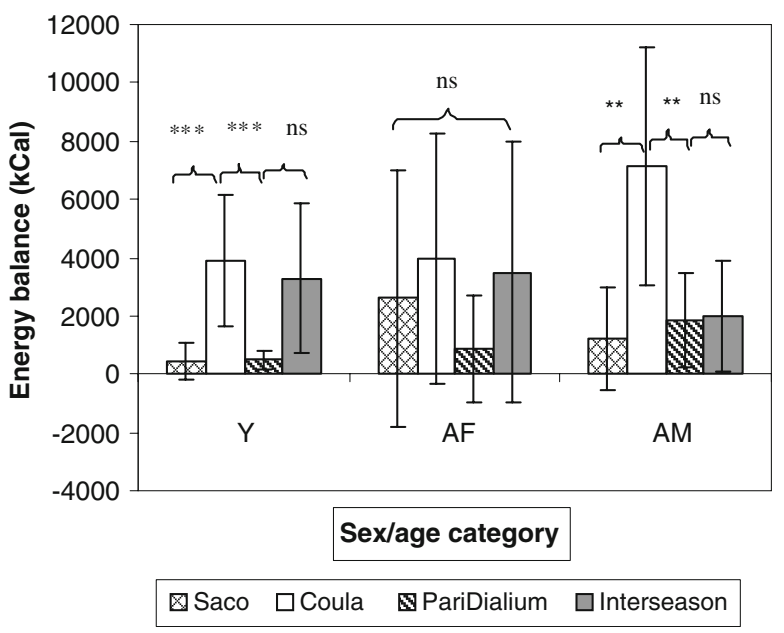

Fig. 2 Seasonal energy balance of chimpanzees of different sex-age categories $\mathrm{Y}=$ young; $\mathrm{AF}=$ adult females; $\mathrm{AM}=$ adult males; $\mathrm{ns}=$ nonsignificant; $* * p<0.01 ; * * * p<0.001$.

days only during the Saco season (27\% of days) and adult males experienced negative energy balance days during the Saco and the Parinari-dialium seasons (12\% of days for both cases), whereas adult females faced days with negative energy balance during all fruit seasons (Saco: $31 \%$, Coula: $9 \%$, Parinari-dialium: $56 \%$ and Interseason: $33 \%)$.

Adult female DJLs were a function of ripe fruits and energy availability. DJLs during periods of low food availability (Saco season) were significantly shorter than during periods of high food availability (Coula season) $\left(\mathrm{X}^{2}=15.26 ; N=195 ; \mathrm{df}=3\right.$; $p=0.002$; Fig. 3). There is a significant correlation between food availability and adult female DJLs only during the Saco season. Contrary to our prediction, the correlation was negative $\left(r_{\mathrm{s}}=-0.523 ; N=26 ; p=0.006\right)$. We did not observe any variation in DJL across seasons in adult males and young individuals.

There is a significant negative correlation between food availability and feeding time $\left(r_{\mathrm{s}}=-0.219 ; N=195 ; p=0.002\right)$, suggesting that chimpanzees reduce feeding time during periods of high food availability.

There is no significant influence of biomass abundance and fruit diversity on energy balance $\left(R^{2}=0.48 ; F_{(4 ; 122)}=28.71 ; p<0.001\right.$; Table II).

Table II Influence of different parameters of food availability on daily energy balance in Taï chimpanzees

\begin{tabular}{llll}
\hline Independent variables & Coefficients of regression & t-Test & $p$ \\
\hline Biomass abundance & -0.002 & -0.98 & 0.328 \\
Diversity & 4.34 & 0.08 & 0.934 \\
Energy providing rate & 117.61 & 9.06 & $<0.001$ \\
\hline
\end{tabular}




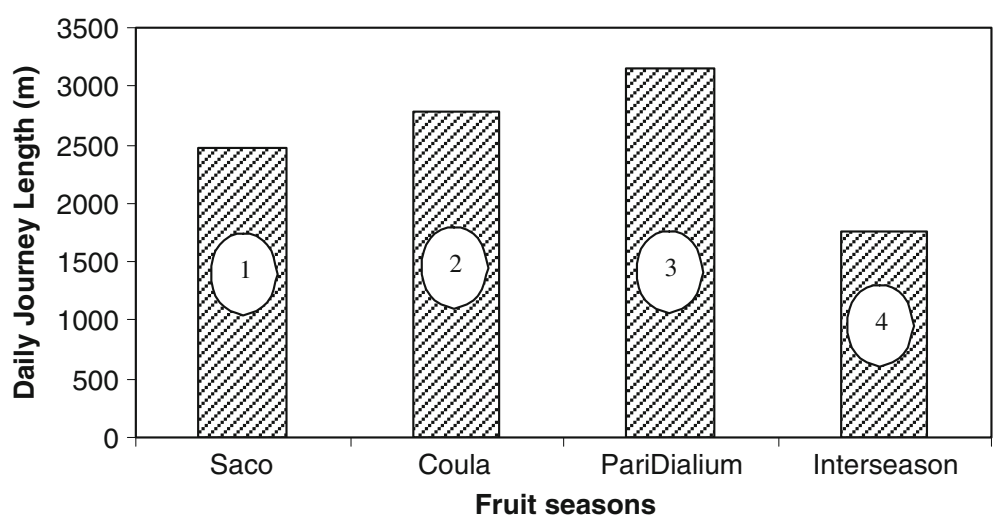

Fig. 3 Daily journey length in Taï chimpanzees in 4 different fruit seasons. (1-2 ns; $1-3 * ; 1-4$ ns; 2-3: ns; $2-4 * * ; 3-4 * * *)$.

\section{Protein Gain}

There is no significant difference in mean daily protein gain between age-sex categories $\left(\chi^{2}=5.454, N=114, \mathrm{df}=2, \mathrm{p}=0.06\right)$. Daily protein gain was higher during the Coula season than other seasons for adult males (Coula $>$ Saco: $U=8, N=17$, $p=0.006$; Coula > Parinari-dialium: $U=12, N=17, p=0.021$ ), and for young individuals (Coula > Saco: $U=33, N=24, p=0.026$; Coula > Parinari-dialium: $U=20, N=24, p=0.002)$. There is no significant variation in daily protein gain across fruit seasons for adult females $\left(\chi^{2}=4.008, N=48, \mathrm{df}=3, p=0.261\right.$; Fig. 4).

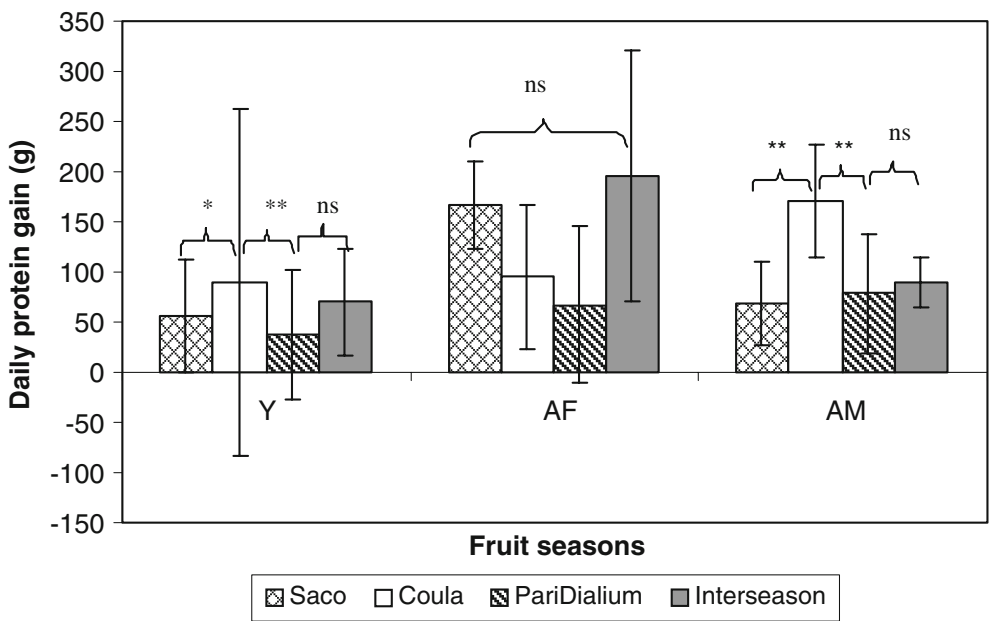

Fig. 4 Seasonal variation in daily protein gain among Taï chimpanzees for 3 sex-age categories. Y= young; $\mathrm{AF}$ adult females; $\mathrm{AM}=$ adult males; $\mathrm{ns}=$ nonsignificant; $* p<0.05 ; * * p<0.01$. 


\section{Discussion}

Although detailed, our study of energy balance and protein gain in a well habituated chimpanzee community must be considered preliminary because most data on energy expenditure are extrapolated from either human or captive chimpanzee data, and we have no means of knowing how this reflects the reality of wild chimpanzees. Problems related to wild food digestibility, as discussed by Conklin-Brittain et al. (2006), are also relevant, and the small size of the focal community may also limit the extrapolation of our results to other chimpanzees. Despite these important concerns, we can consider this study as a baseline for future studies.

Although overall energy balance was on average positive for all fruit seasons, the common occurrence of days with negative energy balance is important. Adult females, in particular, spent up to half of their days with a negative energy balance in all seasons, suggesting that individuals face food limitations in the forest during certain seasons. We do not have a precise indication as to how quickly negative days are balanced by positive days, because we did not follow the same target during consecutive days. Positive energy balances are understandable for young individuals as they are growing, but our overall finding of positive energy balance in adult males may reflect errors in our estimates, although adult males in our study are relatively young: 16 and 22 yr. Both overestimation of energy intake and underestimation of energy expenditure are potential sources of error in our data. Adapting doubly labeled water experiments (Tooze et al. 2007; Trabulsi et al. 2003), which allow direct measurements, to wild conditions could correct some of the limitations of our study and improve future studies concerning estimates of total daily energy expenditure in wild chimpanzees.

Researchers have observed seasonal variation in, as well as limitations on, nutrient and energy gain in other species, such as baboons (Altmann et al. 1993; Byrne et al. 1993) and orangutans (Knott 1998). Seasonal variation in energy balance is in accordance with the characteristics of the different fruit seasons. Energy balance is higher during the Coula season when fruits provide high amounts of energy. This is further aided by the use of a hammer to crack nuts, a highly efficient technology (Boesch and Boesch-Achermann 2000). During the low energy providing Saco season, the energy balance remained low, despite the consumption of large amounts of Sacoglottis gabonensis through wadging. Wadging is an efficient but time-consuming technique for extracting sugar from fruit pulp. Our finding that energy balance is influenced more by the rate at which energy is gained than by biomass abundance suggests that we must pay particularly close attention to the quality of food available when we consider primate feeding ecology. This may explain why Conklin-Brittain et al. (2006) found no significant correlation between fruit availability and energy intake in the chimpanzees of Kibale, Uganda.

When confronted with seasonal variation in food availability and potential energetic deficiencies, chimpanzees react by altering certain components of their energy balance. Chimpanzees reduce DJL during seasons in which energy gain is low. However, during times of low food availability (the Saco season), chimpanzees increase their DJL, presumably to find food. During the same season, chimpanzees also increase their feeding time. These results are in accordance with other studies on the relationship between seasonal variation in food availability and primate behavior (Gursky 2000; Hill and Dunbar 2002; Overdorff 1993). For example, Doran (1997) 
suggested that Taï chimpanzees devoted more time to feeding and reduced their DJL during low food availability. Our finding that chimpanzees fed for longer periods on foods of low nutritional value, seemingly to compensate for the nutritional deficit of the food, is also in line with previous work on other primate species (Hladik 1977; Oates 1987; Richard 1985). Dunbar (1988) and Malenky and Wrangham (1994) suggested 2 strategies to compensate for low food availability periods: either traveling long distances to obtain more food or reducing travel distances to save energy. In our study, Taï chimpanzees used the latter strategy to deal with the unpredictable fluctuations of food availability in the forest.

The similarity in protein gain between young and adult chimpanzees may be due to the higher per unit body mass protein requirement of young individuals. Adult female protein gain is stable across fruit seasons, although they are either pregnant or lactating. Because observed values of daily protein gain are sometimes lower than theoretical values (National Research Council 2003), it would be desirable to follow the protein gain of chimpanzees closely in long-term studies to determine whether eventual protein deficiency occurs.

This study reveals that despite the apparent abundance of food in evergreen rain forests (White 1998), meeting basic nutritional requirements may be a real challenge for individuals in our chimpanzee focal community because we detected negative energy balances in all individuals studied. Nevertheless, individuals were able to obtain an overall positive balance in all seasons. This is the result of flexible behaviors, whereby individuals walk longer DJLs and increase feeding times during lean seasons. Precise studies of whole-day nutritional balances of focal individuals have the potential to reveal new aspects of the interactions between food availability and food consumption, as well as yielding a better understanding of the role of food supply plays on the survivorship and reproductive success of wild primates.

Acknowledgments We thank the Ministry of Water-Forest and Environment and the Ministry of Scientific Research of Côte d'Ivoire for permission to work at Taï National Park and the University of Cocody and the Swiss Center for Scientific Research for academic support, as well as the Park Director for permitting access to the park. We thank field assistants Jonas Tahou and Honora Kpazahi for their contribution to the success of this work, as well as the laboratory technicians, Doreen Pick and Heidrun Barleben, for their help at IZW in Berlin. We extend special warm thanks to Roger Mundry for his excellent statistical advice and to Mimi Arandjelovic for useful comments on the manuscript. We thank the anonymous reviewers who improved this work. A.N. expresses its gratitude to Pr. Eliezer N'goran, his $\mathrm{PhD}$ director, for constant support. We are deeply grateful to Max Planck Institute for Evolutionary Anthropology and Swiss Centre of Scientific Research for their financial support.

Open Access This article is distributed under the terms of the Creative Commons Attribution Noncommercial License which permits any noncommercial use, distribution, and reproduction in any medium, provided the original author(s) and source are credited.

\section{References}

Altmann, J. (1974). Observational study of behavior: Sampling methods. Behaviour, 49, $227-267$. doi:10.1163/156853974X00534.

Altmann, J., Schoeller, D., Altmann, S. A., Muruthi, P., \& Sapolsky, R. M. (1993). Body size and fatness of free-living baboons reflect food availability and activity levels. American Journal of Primatology, 30, 149-161. doi:10.1002/ajp.1350300207. 
Anderson, D. P., Nordheim, E. V., Boesch, C., \& Moermond, T. C. (2002). Factors influencing fissionfusion grouping in chimpanzees in Tai National Park, Cote d'Ivoire. In C. Boesch, G. Hohmann \& L. F. Marchant (Eds.), Behavioural diversity in chimpanzees and bonobos. Cambridge, UK: Cambridge University Press.

Aubréville, A. (1936). La flore forestière de la Côte d'Ivoire. Paris: Larose Éditeurs.

Ausman, L. M., Gallina, D. L., \& Hegsted, D. M. (1989). Protein-calorie malnutrition in squirrel monkeys: Adaptive response to calorie deficiency. American Journal of Clinical Nutrition, 50, 19-29.

Barton, R. A. (1992). Allometry of food intake in free-ranging anthropoid primates. Folia Primatologica, 58, 56-59. doi:10.1159/000156608.

Billat, V., Palleja, P., Charlaix, T., Rizzardo, P., \& Janel, N. (1995). Energy specificity of rock climbing and aerobic capacity in competitive sport rock climbers. Journal of Sports Medicine and Physical Fitness, 35, 20-24.

Boesch, C., \& Boesch-Achermann, H. (2000). The chimpanzees of the Taï Forest: Behavioural ecology and evolution. Oxford and New York: Oxford University Press.

Boesch, C., Gone Bi, Z. B., Anderson, D. P., \& Stahl, D. (2006). Food choice in Tai chimpanzees: Are cultural differences present? In G. Hohmann, M. M. Robbins \& C. Boesch (Eds.), Feeding ecology in apes and other primates (pp. 183-201). Cambridge, UK: Cambridge University Press.

Booth, J., Marino, F., Hill, C., \& Gwinn, T. (1999). Energy cost of sport rock climbing in elite performers. British Journal of Sports Medicine, 33, 14-18. doi:10.1136/bjsm.33.1.14.

Buckee, G. K. (1994). Determination of total nitrogen in barley, malt and beer by Kjeldahl procedures and the Dumas combustion method-Collaborative Trial. Journal of the Institute of Brewing, 100, 57-64. Institute of Brewing (Great Britain).

Byrne, R. W., Whiten, A., Henzi, S. P., \& McCulloch, F. M. (1993). Nutritional constraints on mountain baboons (Papio arsinus): Implication for baboon socioecology. Behavioral Ecology and Sociobiology, 33, 233-246. doi:10.1007/BF02027120.

Chivers, D. J. (1998). Measuring food intake in wild animals: Primates. Proceedings of the Nutrition Society, 57, 321-332. doi:10.1079/PNS19980047.

Conklin-Brittain, N. L., Knott, C. D., \& Wrangham, R. (2006). Energy intake by wild chimpanzees and orangutans: Methodological considerations and preliminary comparison. In G. Hohmann, M. M. Robbins \& C. Boesch (Eds.), Feeding ecology in apes and other primates (pp. 445-465). Cambridge, UK: Cambridge University Press.

Coward, W. A., \& Lunn, P. G. (1981). The biochemistry and physiology of kwashiorkor and marasmus. British Medical Bulletin, 37, 19-24.

Doran, D. (1997). Influence of seasonality on activity patterns, feeding behavior, ranging, and grouping patterns in Tai chimpanzees. International Journal of Primatology, 18, 183-206. doi:10.1023/ A:1026368518431.

Dunbar, R. I. M. (1988). Primate social systems. Ithaca, NY: Comstock Pub. Associates, Cornell University Press.

Food and Agriculture Organization of the United Nations, United Nations University. \& World Health Organization. (2004). Human energy requirements: Report of a Joint FAO/WHO/UNU Expert Consultation: Rome, October 17-24, 2001. FAO food and nutrition technical report series. Rome: Food and Agricultural Organization of the United Nations.

Goodall, J. (1986). The chimpanzees of Gombe: Patterns of behavior. Cambridge, MA: Belknap Press of Harvard University Press.

Günther, M. M., \& Boesch, C. (1993). Energetic cost of nut-cracking behaviour in wild chimpanzees. In H. Preuschoft \& D. J. Chivers (Eds.), Hands of primates (pp. 109-129). Vienna: Springer.

Gursky, S. (2000). Effect of seasonality on the behavior of an insectivorous primate, Tarsius spectrum. International Journal of Primatology, 21, 477-495. doi:10.1023/A:1005444020059.

Hill, R. A., \& Dunbar, R. I. M. (2002). Climatic determinants of diet and foraging behaviour in baboons. Evolutionary Ecology, 16, 579-593. doi:10.1023/A:1021625003597.

Hladik, C. M. (1977). A comparative study on feeding strategies of two sympatric species of leaf-monkey Presbytis senex and Presbytis entellus. In T. H. Clutton-Brock (Ed.), Primate ecology (pp. 323-353). London: Academic Press.

Hunt, K. D. (1989). Positional behavior in Pan troglodytes at the Mahale Mountains and the Gombe Stream National Parks, Tanzania.

Key, C., \& Ross, C. (1999). Sex differences in energy expenditure in non-human primates. Proceedings of the Royal Society of London. Series B: Biological Sciences, 266, 2479-2485. doi:10.1098/ rspb.1999.0949. 
Kindt, E., Motzfeldt, K., Halvorsen, S., \& Lie, S. O. (1983). Protein requirements in infants and children: A longitudinal study of children treated for phenylketonuria. American Journal of Clinical Nutrition, 37, 778-785.

Kleiber, M. (1947). Body size and metabolic rate. Physiological Reviews, 27, 511-541.

Knott, C. D. (1998). Changes in orangutan caloric intake, energy balance, and ketones in response to fluctuating fruit availability. International Journal of Primatology, 19, 1061-1079. doi:10.1023/ A:1020330404983.

Kurland, J. A., \& Pearson, J. D. (1986). Ecological significance of hypometabolism in nonhuman primates: Allometry, adaptation, and deviant diets. American Journal of Physical Anthropology, 71, 445-457. doi:10.1002/ajpa.1330710408.

Leonard, W. R., \& Robertson, M. L. (1997). Comparative primate energetics and hominid evolution. American Journal of Physical Anthropology, 102, 265-281. doi:10.1002/(SICI)1096-8644(199702) 102:2<265::AID-AJPA8>3.0.CO;2-X.

Livesey, G. (1995). Metabolizable energy of macronutrients. American Journal of Clinical Nutrition, 62, $1135 \mathrm{~S}-1142 \mathrm{~S}$.

Livesey, G. (2001). A perspective on food energy standards for nutrition labelling. British Journal of Nutrition, 85, 271-287.

Malenky, R. K., \& Wrangham, R. W. (1994). A quantitative comparison of terrestrial herbaceous foodconsumption by Pan paniscus in the Lomako Forest, Zaire, and Pan troglodytes in the Kibale Forest, Uganda. American Journal of Primatology, 32, 1-12. doi:10.1002/ajp.1350320102.

Martin, P. R., \& Bateson, P. P. G. (1986). Measuring behaviour: An introductory guide. New York: Cambridge University Press.

Mermier, C. M., Robergs, R. A., McMinn, S. M., \& Heyward, V. H. (1997). Energy expenditure and physiological responses during indoor rock climbing. British Journal of Sports Medicine, 31, 224228. doi:10.1136/bjsm.31.3.224.

National Research Council.N. (2003). Nutrient requirements of nonhuman primates. Washington, DC: National Academy Press.

Nishida, T. (1990). The Chimpanzees of the Mahale mountains: Sexual and life history strategies. Tokyo: University of Tokyo Press.

Oates, J. F. (1987). Food distribution and foraging behavior. In B. B. Smuts, D. L. Cheney, R. M. Seyfarth, R. W. Wrangham \& T. T. Struhsaker (Eds.), Primate societies (pp. 197-209). Chicago: University of Chicago Press.

Overdorff, D. J. (1993). Similarities, differences, and seasonal patterns in the diets of Eulemur rubriventer and Eulemur fulvus rufus in the Ranomafana-National Park, Madagascar. International Journal of Primatology, 14, 721-753. doi:10.1007/BF02192188.

Pellet, P. L. (1990). Protein requirements in humans. American Journal of Clinical Nutrition, 51, $723-737$.

Pontzer, H., \& Wrangham, R. W. (2004). Climbing and the daily energy cost of locomotion in wild chimpanzees: Implications for hominoid locomotor evolution. Journal of Human Evolution, 46, 317335. doi:10.1016/j.jhevol.2003.12.006.

Pusey, A. E. (1990). Behavioral changes at adolescence in chimpanzees. Behaviour, 115, $203-246$. doi:10.1163/156853990X00581.

Richard, A. F. (1985). Primates in nature. New York: W. H. Freeman.

Savini, T., Boesch, C., \& Reichard, U. H. (2008). Home-range characteristics and the influence of seasonality on female reproduction in white-handed gibbons (Hylobates lar) at Khao Yai National Park, Thailand. American Journal of Physical Anthropology, 135, 1-12. doi:10.1002/ajpa.20578.

Smith, R. J., \& Jungers, W. L. (1997). Body mass in comparative primatology. Journal of Human Evolution, 32, 523-559. doi:10.1006/jhev.1996.0122.

Sockol, M. D., Raichlen, D. A., \& Pontzer, H. (2007). Chimpanzee locomotor energetics and the origin of human bipedalism. Proceedings of the National Academy of Sciences of the United States of America, 104, 12265-12269. doi:10.1073/pnas.0703267104.

Taylor, C. R., Heglund, N. C., \& Maloiy, G. M. O. (1982). Energetics and mechanics of terrestrial locomotion: Metabolic energy consumption and as a function of speed and body size in birds and mammals. Journal of Experimental Biology, 97, 1-21.

Tooze, A. J., Schoeller, D., Subar, A. F., Kipnis, V., Schatzkin, A., \& Troiano, R. P. (2007). Total daily energy expenditure among middle-aged men and women: The OPEN Study. American Journal of Clinical Nutrition, 86, 382-387.

Trabulsi, J., Troiano, R. P., Subar, A. F., Sharbaugh, C., Kipnis, V., Schatzkin, A., et al. (2003). Precision of the doubly labeled water method in a large-scale application: Evaluation of a streamlined-dosing 
protocol in the Observing Protein and Energy Nutrition (OPEN) study. European Journal of Clinical Nutrition, 57, 1370-1377. doi:10.1038/sj.ejcn.1601698.

Van Soest, P. J. (1994). Nutritional ecology of the ruminant. Ithaca, NY: Comstock Pub.

Watts, P. B., \& Drobish, K. M. (1998). Physiological responses to simulated rock climbing at different angles. Medicine and Science in Sports and Exercise, 30, 1118-1122. doi:10.1097/00005768199807000-00015.

Watts, P. B., Daggett, M., Gallagher, P., \& Wilkins, B. (2000). Metabolic response during sport rock climbing and the effects of active versus passive recovery. International Journal of Sports Medicine, 21, 185-190. doi:10.1055/s-2000-302.

White, F. J. (1998). Seasonality and socioecology: The importance of variation in fruit abundance to bonobo sociality. International Journal of Primatology, 19, 1013-1027. doi:10.1023/ A:1020374220004.

Whitehead, R. G. (1980). Animal models for the study of protein-energy malnutrition. Proceedings of the Nutrition Society, 39, 227-231. doi:10.1079/PNS19800037.

Whiten, A., Byrne, R. W., Barton, R. A., Waterman, P. G., \& Henzi, S. P. (1991). Dietary and foraging strategies of baboons. Philosophical Transactions of the Royal Society of London. Series B, Biological Sciences, 334, 187-197. doi:10.1098/rstb.1991.0108.

Wilgram, G. F., Lucas, C. C., \& Best, C. H. (1958). Kwashiorkor type of fatty liver in primates. Journal of Experimental Medicine, 108, 361-371. doi:10.1084/jem.108.3.361.

Zihlman, A. L., Stahl, D., \& Boesch, C. (2007). Morphological variation in adult chimpanzees (Pan troglodytes verus) of the Tai National Park, Cote d'Ivoire. American Journal of Physical Anthropology, 000, 1-8. 